\title{
Organizational Performance and Retail Challenges: A Structural Equation Approach
}

\author{
Rajwinder Singh ${ }^{1}$, Harminder Singh Sandhu' ${ }^{2}$, Bhimaraya A. Metri ${ }^{3}$, Rajinder Kaur ${ }^{4}$ \\ ${ }^{1}$ School of Management Studies, Punjabi University Patiala, Patiala, India; ${ }^{2}$ Commerce and Business Management, Guru Nanak Dev \\ University, Amritsar, India; ${ }^{3}$ Management Development Institute, Gurgaon, India; ${ }^{4}$ Rajinder Kaur, Malout Institute of Management \\ and Information Technology, Malout, India. \\ Email: \{rajwindergheer, riya07rajinder\}@gmail.com, sandhu_hs12@yahoo.com; metri@mdi.ac.in
}

Receive February $5^{\text {th }}, 2011$; revised April 16 ${ }^{\text {th }}, 2011$; accepted April 26 $6^{\text {th }}, 2011$.

\begin{abstract}
Organized retailing is a sunrise industry in India. Many big industrial houses and international players are in the arena. The perfect competition in the market posed many challenges to retailers for better organizational performance. In this study we attempt to identify items for retail challenges $(R C)$ and organizational performance (OP) based on strong literature support in consultation of practitioners and consultants in the field of organized non-livestock retailing (NLR). The retail challenges so selected were classified with factor analysis using principal component analysis with varimax rotation. Here, the retail challenges are classified into four categories as: strategic challenges, environmental challenges, customer challenges, and supply chain (SC) challenges. The six identified items for organizational performance are: market performance, SC competencies, stakeholder satisfaction, innovation and learning, customer satisfaction, and financial performance. A confirmatory model was tested using structural equation modeling to prove hypotheses: strategic challenges, environmental challenges, and customer challenges influence SC challenges and all the challenges affect organizational performance. The data were collected from organized non-livestock retail players operating in north India. All the results are validated using rigorous statistical analysis.
\end{abstract}

Keywords: Organized Retailing, Organizational Performance, Retail Challenges, Structural Equation Modeling, Factor Analysis

\section{Introduction}

Retailing is the set of activities that markets products or services to the final consumers for their personal or household use. In India this industry is identified as 'karyana' stores. These karyana stores have been in use since ages. The organized non-livestock retailing (NLR) is the sale of agriculture and horticulture products to consumers. The concept of organized retailing gained momentum in 1980 when Mother's Dairy introduced vegetables and milk at the retail outlets in New Delhi. Later on Verka, Amul, Markfed have followed the concept and created co-operative societies for seeds, pulses, milk and milk products [1].

The boom in organized retailing came after liberalization in 1991. According to CMIE report the retail growth doubled from 1990 to 1999. In India there are 15 million retailers, operating in the form of "mom pop" outlets spread over 31 million square meters area, generating sales of USD 11 billion in 2007-2008 [2]. The organized retailing which constitutes $6 \%$ of the retailing has come up with new formats of retailing like supermarkets, hypermarkets, malls, department stores, discount stores, specialty stores, convenience stores, kiosks and food court counters [3].

The organized retail accommodated many major players after 1990. There were just three shopping malls in 1990 i.e. Spencer Plaza in Chennai, Ansal Plaza in New Delhi and Cross Roads in Mumbai [4]. The number of retail formats has risen to many thousands by the end of 2007. Now organized retailing has emerged as a sunrise industry in India. Many big industrial houses have diversified into this area. The major retail players in this industry are: Reliance Retail, RPG Retail, The Tata Group, K Raheja Corporation, Piramyd Retail, Nilgiris', Subhiksha Trading Limited, Trinethra, Vishal Group, and BPCL etc. These players have collaborated with the national and international players like Wal-Mart, Tesco, and Metro etc. to harvest the profits.

The intense competition in the market and changing customer preferences has made the retailers' job difficult 
and challenging. It was observed that many retail outlets were opened and some of them were closed. This scenario has attracted the attention of many researchers to find solution for the same. During interaction with the organized NLR the need was identified to understand the retail challenges, and organizational performance.

In this paper an attempt has been made to identify the retail challenges and their effect on organizational performance. The remainder of the paper focuses on these issues. The first section focuses on literature survey on retail challenges. The second section focuses on the organizational performance. The third section focuses on research methodology to design and execute research for the same. In the last section the paper ends with discussion, limitation and space for future research. The technique of factor analysis has been applied to classify factors for retail challenges and technique of structural equation modeling has been applied to test hypotheses.

\section{Retail Challenges}

Organised retail in India is little decade old industry, suffering from many challenges. These challenges are quoted by many researchers as shown in the Table $\mathbf{1}$ as follows:

The discussion with organized NLR and consultants the major retail challenges have been identified as follows:

Product Sourcing: Product sourcing decisions play a very important role to arrange and manage inventory. In organized NLR the product cost is directly linked with it. If the products are arranged from distributor and whole-

Table 1. Retail challenges.

\begin{tabular}{cl}
\hline Author & \multicolumn{1}{c}{ Retail Challenges } \\
\hline [5] & $\begin{array}{l}\text { Retail is not recognized as an industry, High cost of real } \\
\text { estate, High stamp duty, Inadequate infrastructure, Multiple } \\
\text { and complex taxation system, Competitive forces }\end{array}$ \\
[6] & Retail Crimes: Arson, Criminal damage, Sabotage, Robbery \\
[7] & $\begin{array}{l}\text { Karyana stores, High operational costs, Requirement of } \\
\text { specialization, Correct marketing mix, Strong IT support, }\end{array}$ \\
Unclear industry status & $\begin{array}{l}\text { Effectiveness of marketing and Advertisement, Product } \\
\text { sourcing, Technological changes, Higher service levels, } \\
\text { Transparency, Management skills and capabilities }\end{array}$ \\
FDI in retail, Lack of recognition as an Industry, Difficulty in \\
procurement and movement of goods, Mismatch in demand \\
and supply, Numerous intermediates, Inefficient supply \\
chains, Poor infrastructure, Availability and cost of real \\
estate, Urban land ceiling, Availability of parking \\
High operational costs, Insufficient investment in strengthen- \\
ing back-end operations, High rate of attrition and retaining a \\
talented workforce
\end{tabular}

saler then product cost would be high as compared to the direct purchase from the farmers. Nowadays the retailers have signed agreements under contract farming with the farmers. Identifying the advantages of sourcing many organized NLR players has owned farms to manage inventory.

Transparency: Transparency is also one of the major challenges for the retailers because the class of customers visiting organized retail stores is qualified enough to compare product quality and cost associated with it. They expect all the information regarding products to be displayed with full authentication otherwise the customer churn rate would be more.

Specialized Skills: The vast variety of inventory and ability to convince and satisfy customers, need highly skilled manpower. It is due to the fact that same/different products have different meanings to different customers. Failing to convince the customers shall result into lost sales.

Manpower Management: During the discussion with organized players it was observed that highly qualified people were not much interested to join this sector. Also after some experience, they leave the job. Hence, it is also one of the major challenges for this sector.

Karyana Stores: These stores are operated by traditional retailers. In most of the cases either they own shop or hire at very low rental charges as compared to organized retailers. It was also observed that most of the karyana stores are located at very prominent locations near residential areas in large numbers. Hence, it is also one of the major challenges for the organized retailers.

Multiple Taxes: Multiple taxes are also one of the major challenges for the organized NLR. The discussion with organized NLR revealed that these taxes add to the record keeping and wastage of time as compared to traditional retailers. It is due to the fact that traditional retailers do not maintain such records. Hence, the performance of organized retailers is much affected as compared to traditional retailers.

Inadequate Infrastructure: It is also one of the major challenges for the organized NLR. It is due to the fact that despite the ambience; the parking facilities, internet access, and delivery facilities are not at par with the developed countries like USA, UK etc. So, it adversely affects the organized NLR performance.

Real Estate Cost: The cost of real estate is very high. This hindrance has adversely affected the organized NLR performance. The traditional retailers have already set the retail stores at the prominent locations in the heart of the cities. Such locations are distant dream for the organized retailers. Hence, it is also one of the major retail challenges for the organized NLR.

Quick Response: The vast variety and pricing dy- 
namics of the market has made the organized retailing a challenging job. The traditional retailers nowadays also offer more variety at competitive prices. Also, the farmers directly sell their produce in the market at the competitive prices in large volume. This helps customers to select the best product from large quantities. They also reduce the cost to very low levels in the evenings, which is not possible in case of organized retailers because, they either purchase from the farmers or wholesalers. Hence, it is difficult for organized retailers to quick respond to the market dynamics. Hence, it is also one of the major challenges for the organized NLR to cope with market dynamics.

Customer Loyalty: The customer segments visiting the organized stores are qualified from middle and high income groups. They have different meaning to same or different products. Hence, customer loyalty is a challenging job. The organization shall easily duplicate the marketing policies but, customer loyalty shall not be duplicated. Hence, it is also one of the major challenges for the organized NLR.

High Connectivity: It is required to understand the customers' expectations and means to meet them. The dynamic nature of NLR business needs high connectivity between customers, markets, and organizations. The failure of which shall lost sale and goodwill. Hence, it is also one of the major challenges affecting organized NLR performance.

Operational Cost: The operational cost of organized stores is very high as compared to the traditional retailers. It is due to the fact that most of the traditional retailers own their shops and manage the operations by their own. Here, the rental charges, manpower cost, and tax burden are very less as compared to organized stores. So, it is also one of the major challenges for the organized retailers.

SC Performance: The competition in the market has shifted to SC vs. SC. The organizations collaborate with national and international players to maximized SC performance. This intense competition has made the job of marginal organized retailers challenging. The big industrial houses also own farm houses and distribution channels making the job of other competitors difficult. Hence, it is also one of the major challenges for this sector.

Forecasting: Demand forecasting is also one of the major challenges for this industry. The price fluctuations, seasonal fluctuations, and changing customer preference has made this job challenging. Hence, it is also one of the major challenges for the organized NLR.

\section{Organizational Performance}

Organizational performance refers to how well an organization achieves its market oriented goals as well as its financial goals [11]. Organizations adopt suitable strategies and policies for better organizational performance (OP). The ultimate objective of all the innovative techniques is to enhance OP. In this study the identified constructs for $\mathrm{OP}$ in consultation of practitioners and consultants in the field of NLR are: market performance, supply chain competencies, stakeholder satisfaction, innovation and learning, customer satisfaction, and financial performance. These are explained as follows:

Market Performance: Market performance is one of the most important factors for OP. The organizations with good market share shall adopt competitive strategies to compete the competitors. Also, the market performance as measured by customer satisfaction is good for OP [12]. Hence, it is one of the major components for OP.

Supply Chain Competencies: Today's intense market competition has shifted to SC vs. SC. An efficient SC shall save more resources and ultimately OP would be better. An attempt to optimize OP, without considering SC may negatively impact OP [13]. Also, the logistics performance reflects the OP as it delivers the products in quantity at the time as per customers' requirements [14]. Hence, it is also one of the major OP components.

Customer Satisfaction: It is one of the most important construct as satisfied customers may be loyal to the organization and revisit for purchase shall be assured. So, it is also identified it as an important construct for better OP [15].

Stakeholders' Satisfaction: Stakeholders are the main elements to develop the financial base of the organization. If they are satisfied then they shall remain members otherwise they shall depart. It is the focal point of the OP measurement process [1]. Hence, it is also one of the major components for OP.

Innovation and Learning: It is also an important construct for better OP. It was seen that many organizations are out of the business due to their failure to learn and innovate. So, it as an important construct for OP [15].

Financial Performance: The ultimate objective of all the organizations is better financial performance. It helps to adopt competitive strategies to leave behind the competitors. Hence, it is also one of the important components for better OP [16,17].

\section{Database and Methodology}

This research is based on primary data. The primary data was collected from the organized NLR organisations with the help of a questionnaire. The questionnaire was developed based on strong literature support in consultation of practitioners and consultants in the field of or- 
ganized NLR. The respondents were selected based on: India Retail Report 2007 \& 2009, Retail Telephone Directory, PROWESS, and Organization websites etc. The unit of analysis was the organized NLR organizations operating in the principal cities of Punjab, Chandigarh, and Gurgaon. The reason for selecting this north India belt was due to, good in agriculture production and establishment of organized retailers in large numbers. The pre-pilot and pilot survey was done to improve the questionnaire. Later on, large scale survey was done at the top, middle and lower level of organized NLR organizations by randomly selecting respondents based on telephone addresses. The questionnaires were mailed after telephonic discussion and later on, were followed for response. A total of 560 questionnaires were sent with receipt of 402 responses $($ Top $=100$, middle $=134$, lower $=168$ ) yielding a response rate of $72 \%$. The technique of factor analysis using principal component analysis with varimax rotation was applied to classify the factors for retail challenges. The technique of confirmatory factor analysis was applied to test the relationship between retail challenges and organizational performance. This research intends to prove the research framework (Figure 1) by developing and testing hypotheses as follows:

H1: Strategic challenges, environmental challenges, and customer challenges influence supply chain challenges: It was evident from the literature survey and discussion with organized players that the market competition has shifted SC vs. SC. Hence, it was assumed that strategic challenges, environmental challenges and customer challenges shall influence SC performance.

H2: All the challenge factors affect organizational performance: The organized NLR organizations design their strategies to cope with these challenges. Hence, it was assumed that all the challenge factors shall be affecting OP.

\subsection{Scale Development}

The six items for OP and seventeen-items for RC were selected based on strong literature support in consultation of practitioners and consultants in the field of organized NLR. Pre-pilot and pilot survey was done to improve the questionnaire. Based on survey comments one item i.e. arson was not found valid for retail challenges in India. Hence, it was deleted yielding the effective RC items to 16. These items were rated on five-point Likert scale on two time horizons to measure the variability in the recorded responses. Later on improved questionnaire was subjected to large scale survey.

\subsection{Scale Refinement}

The questionnaire so developed was tested through prepilot and pilot survey. Later on large survey was done. The improved questionnaire responses were subjected to rigorous statistical analysis as follows:

Item and scale reliability analysis was performed to retain and delete the scale items for the purpose of developing a reliability scale. Here, scale reliability (Cronbach's Alpha), communality, item-to-total and inter-item correlation was applied. The items with low correlation were subject to deletion. The corrected-to-total correlation range from 0.5 to 0.7432 , communality range from 0.659 to 0.987, and Cronbach's Alpha $=0.9002$. Here, it is pertinent to mention that communality $\geq 0.5$, Cronbach's alpha $\geq 0.7$, item-to-total correlation $\geq 0.5$ and inter-item correlation $\geq 0.3$ is good enough for conducting research in social sciences [18]. In this phase all the requirements were met for conducting factor analysis as shown in Tables 2 and $\mathbf{3 .}$

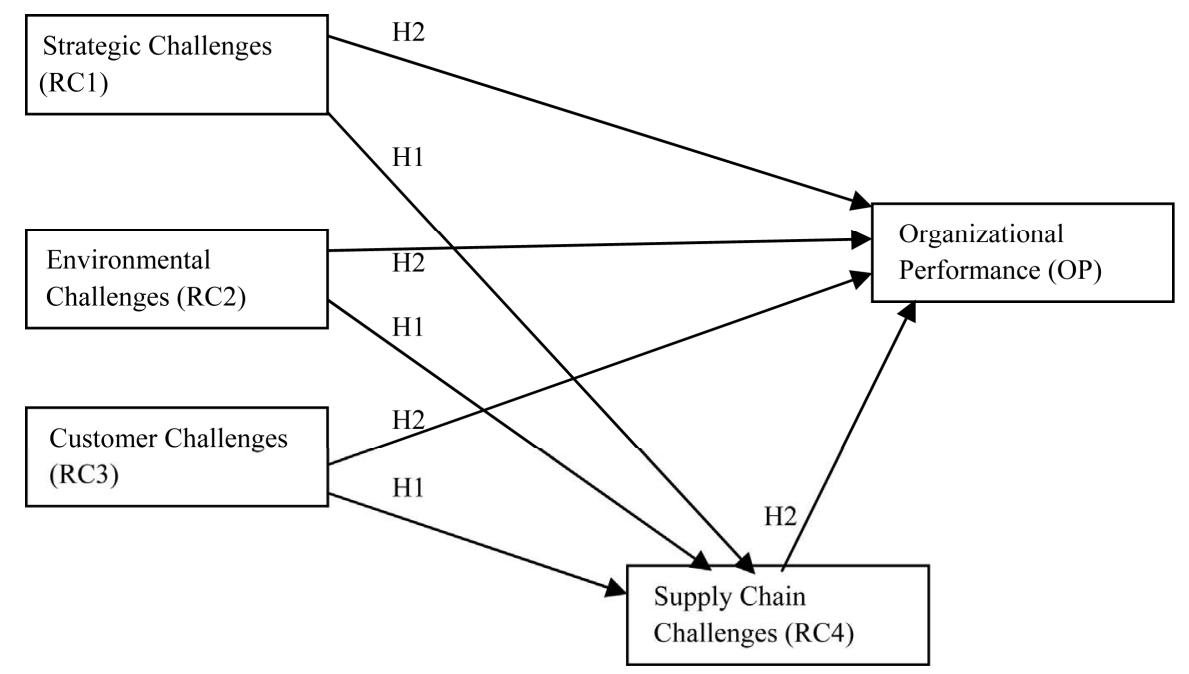

Figure 1. Proposed research framework. 
Table 2. Mean, standard, deviation, corrected item-to-total correlation, scale reliability and communality for retail challenges.

\begin{tabular}{|c|c|c|c|c|c|c|c|}
\hline \multirow[t]{2}{*}{ Code } & \multirow[t]{2}{*}{ Items } & \multirow[t]{2}{*}{ Mean } & \multirow[t]{2}{*}{$\mathrm{SD}$} & \multirow{2}{*}{$\begin{array}{c}\text { Corrected } \\
\text { Item-Total } \\
\text { Correlation }\end{array}$} & \multirow{2}{*}{$\begin{array}{l}\text { Alpha } \\
\text { if Item } \\
\text { Deleted }\end{array}$} & \multicolumn{2}{|c|}{ Communality } \\
\hline & & & & & & Initial & Extracted \\
\hline $\mathrm{C} 1$ & Real Estate Cost & 3.3607 & 1.1676 & 0.7432 & 0.8873 & 1.0 & 0.987 \\
\hline $\mathrm{C} 2$ & Multiple Taxes & 3.4403 & 1.0976 & 0.6077 & 0.8934 & 1.0 & 0.977 \\
\hline $\mathrm{C} 3$ & Inadequate Infrastructure & 3.3632 & 1.1550 & 0.7117 & 0.8888 & 1.0 & 0.970 \\
\hline $\mathrm{C} 4$ & Karyana Stores & 3.4502 & 1.0935 & 0.5657 & 0.8953 & 1.0 & 0.981 \\
\hline $\mathrm{C} 5$ & Specialized Skills & 3.8209 & 0.9876 & 0.6126 & 0.8927 & 1.0 & 0.970 \\
\hline C6 & Transparency & 3.8209 & 0.9774 & 0.6130 & 0.8927 & 1.0 & 0.967 \\
\hline $\mathrm{C} 7$ & Manpower Management & 3.8159 & 0.9739 & 0.5946 & 0.8934 & 1.0 & 0.948 \\
\hline $\mathrm{C} 8$ & Product Sourcing & 3.8383 & 0.9638 & 0.5857 & 0.8938 & 1.0 & 0.970 \\
\hline $\mathrm{C} 10$ & High Connectivity & 4.4303 & 0.5793 & 0.5559 & 0.8957 & 1.0 & 0.858 \\
\hline $\mathrm{C} 11$ & Quick Response & 4.4353 & 0.5624 & 0.5355 & 0.8963 & 1.0 & 0.854 \\
\hline $\mathrm{C} 12$ & Service levels & 4.4403 & 0.5540 & 0.5040 & 0.8971 & 1.0 & 0.833 \\
\hline $\mathrm{C} 14$ & Operational Cost & 4.8159 & 0.6245 & 0.5950 & 0.8944 & 1.0 & 0.859 \\
\hline $\mathrm{C} 15$ & Forecasting & 4.8930 & 0.4069 & 0.5301 & 0.8978 & 1.0 & 0.659 \\
\hline $\mathrm{C} 16$ & SC Performance & 4.8881 & 0.4236 & 0.5000 & 0.8987 & 1.0 & 0.697 \\
\hline C9 & Customer Loyalty & 4.4254 & 0.6039 & 0.5566 & 0.8955 & 1.0 & 0.847 \\
\hline $\mathrm{C} 13$ & Operations Management & 4.7289 & 0.8841 & 0.5931 & 0.8934 & 1.0 & 0.867 \\
\hline
\end{tabular}

$\mathrm{N}$ of Cases $=402.0, \mathrm{~N}$ of Items $=16, \mathrm{Alpha}=0.9002 ;$ Statistics for Scale: Mean $=65.9677 ;$ Variance $=75.2832 ; \mathrm{Std}$ Dev $=8.6766$.

Table 3. Correlation for retail challenges.

\begin{tabular}{|c|c|c|c|c|c|c|c|c|c|c|c|c|c|c|c|c|}
\hline & $\mathrm{C} 1$ & $\mathrm{C} 2$ & $\mathrm{C} 3$ & $\mathrm{C} 4$ & $\mathrm{C} 5$ & C6 & $\mathrm{C} 7$ & $\mathrm{C} 8$ & C9 & $\mathrm{C} 10$ & $\mathrm{C} 11$ & $\mathrm{C} 12$ & $\mathrm{C} 13$ & $\mathrm{C} 14$ & $\mathrm{C} 15$ & C16 \\
\hline $\mathrm{C} 1$ & 1.0 & & & & & & & & & & & & & & & \\
\hline $\mathrm{C} 2$ & 0.956 & 1.0 & & & & & & & & & & & & & & \\
\hline $\mathrm{C} 3$ & 0.970 & 0.942 & 1.0 & & & & & & & & & & & & & \\
\hline $\mathrm{C} 4$ & 0.941 & 0.971 & 0.942 & 1.0 & & & & & & & & & & & & \\
\hline $\mathrm{C} 5$ & 0.203 & 0.082 & 0.180 & 0.038 & 1.0 & & & & & & & & & & & \\
\hline C6 & 0.205 & 0.088 & 0.190 & 0.052 & 0.964 & 1.0 & & & & & & & & & & \\
\hline $\mathrm{C} 7$ & 0.208 & 0.071 & 0.175 & 0.036 & 0.946 & 0.935 & 1.0 & & & & & & & & & \\
\hline $\mathrm{C} 8$ & 0.183 & 0.082 & 0.185 & 0.050 & 0.960 & 0.959 & 0.941 & 1.0 & & & & & & & & \\
\hline C9 & 0.450 & 0.413 & 0.454 & 0.363 & 0.199 & 0.193 & 0.163 & 0.131 & 1.0 & & & & & & & \\
\hline $\mathrm{C} 10$ & 0.482 & 0.450 & 0.440 & 0.426 & 0.157 & 0.158 & 0.128 & 0.112 & 0.816 & 1.0 & & & & & & \\
\hline C11 & 0.455 & 0.428 & 0.428 & 0.406 & 0.190 & 0.165 & 0.133 & 0.135 & 0.790 & 0.801 & 1.0 & & & & & \\
\hline $\mathrm{C} 12$ & 0.413 & 0.390 & 0.400 & 0.384 & 0.144 & 0.206 & 0.132 & 0.152 & 0.751 & 0.776 & 0.792 & 1.0 & & & & \\
\hline $\mathrm{C} 13$ & 0.356 & 0.134 & 0.314 & 0.096 & 0.533 & 0.515 & 0.562 & 0.490 & 0.310 & 0.287 & 0.258 & 0.224 & 1.0 & & & \\
\hline C14 & 0.358 & 0.140 & 0.314 & 0.100 & 0.521 & 0.501 & 0.502 & 0.481 & 0.301 & 0.275 & 0.243 & 0.206 & 0.885 & 1.0 & & \\
\hline $\mathrm{C} 15$ & 0.291 & 0.128 & 0.247 & 0.086 & 0.461 & 0.441 & 0.441 & 0.407 & 0.429 & 0.280 & 0.248 & 0.209 & 0.675 & 0.668 & 1.0 & \\
\hline $\mathrm{C} 16$ & 0.253 & 0.085 & 0.211 & 0.044 & 0.417 & 0.397 & 0.397 & 0.365 & 0.226 & 0.359 & 0.163 & 0.126 & 0.684 & 0.676 & 0.523 & 1.0 \\
\hline
\end{tabular}

\subsection{Factor Analysis for Retail Challenges}

The maximum scale score would be 80 if all the 16 items were rated as 5. However, the mean score (Table 2) of 65.9677 indicates that $82.46 \%$ of the items indicated in the questionnaire support their applicability in organized NLR. The factor analysis was done with principal component analysis using varimax rotation. The value for Kaiser-Meyer-Olkin (KMO) Measure of Sampling Ade- quacy was 0.774 , Cronbach's Alpha for factors range from 0.8706 to 0.9877 , the factor loadings range from 0.745 to 0.958 , the vales for Bartlett's Test of Sphericity were: Chi-square $=10528.597$, degree of freedom $=120$, and level of significance $(p)=0.000$. Here, it is pertinent to mention that KMO $\geq 0.7$, Cronbach's Alpha $\geq 0.7, \mathrm{p} \geq$ 0.05 , and factor loading $\geq 0.5$ is good for the validity of factor analysis results [18-20]. The results for factor analysis are shown in Table 4. 
Table 4. Factor analysis results for retail challenges.

\begin{tabular}{|c|c|c|c|c|}
\hline \multirow{2}{*}{ Items } & \multicolumn{4}{|c|}{ Components } \\
\hline & 1 & 2 & 3 & 4 \\
\hline Product Sourcing & 0.958 & & & \\
\hline Transparency & 0.945 & & & \\
\hline Specialized Skills & 0.940 & & & \\
\hline Manpower Management & 0.930 & & & \\
\hline Karyana Stores & & 0.966 & & \\
\hline Multiple Taxes & & 0.959 & & \\
\hline Inadequate Infrastructure & & 0.939 & & \\
\hline Real Estate Cost & & 0.934 & & \\
\hline Quick Response & & & 0.888 & \\
\hline Service levels & & & 0.885 & \\
\hline High Connectivity & & & 0.869 & \\
\hline Customer Loyalty & & & 0.868 & \\
\hline Operational Cost & & & & 0.867 \\
\hline Operations Management & & & & 0.862 \\
\hline SC Performance & & & & 0.809 \\
\hline Forecasting & & & & 0.745 \\
\hline Eigen Value & 6.824 & 4.012 & 1.923 & 1.484 \\
\hline$\%$ Variance & 42.650 & 25.072 & 10.017 & 9.276 \\
\hline Scale Reliability Cronbach's Alpha & 0.9872 & 0.9877 & 0.9365 & 0.8706 \\
\hline
\end{tabular}

$\mathrm{KMO}=0.774$, Bartlett's Test of Sphericity: Chi-square $=10528.597 ; \mathrm{df}=120 ; \mathrm{p}=0.000$.

\subsection{Explanation of Factor Analysis Results for Retail Challenges}

RC1 (Strategic Challenges): This was the most important category covering four items-product sourcing, transparency, specialized skills, and manpower management. This category explains the percentage variance of $42.65 \%$ with Eigen value of 6.842 . The factor loadings range from 0.930 to 0.958 with Cronbach's Alpha of 0.9872 . The items covered are in consonance with the studies quoted in Table 1.

RC2 (Environmental Challenges): This was the second important category covering four items-karyana stores, multiple taxes, inadequate infrastructure, and real estate cost. It explains $25.072 \%$ of variance with Eigen value of 4.012 and Cronbach's Alpha of 0.9877. The factor loadings range from 0.934 to 0.966 . The items covered here are also in consonance with the studies quoted in Table 1.

RC3 (Customer Challenges): This was the third important category with $10.017 \%$ of variance, 1.923 Eigen value and Cronbach's Alpha of 0.9365 . The factor loadings range from 0.868 to 0.888 . The items covered-quick response, service levels, high connectivity, and customer loyalty are in consonance with studies quoted in Table 1.

RC4 (Supply Chain Challenges): This was the last important category covering-operational cost, operations management, SC performance, and demand forecasting. These items with Eigen value of 1.484 explain 9.276\% of variance with loading range from 0.745 to 0.867 and Cronbach's Alpha of 0.8706 . The items covered here are also in consonance with studies quoted in Table 1.

\subsection{Confirmatory Factor Model for Retail Challenges and Organizational Performance}

The research framework is shown in Figure 1. Six items were selected for OP (market performance, SC competencies, stakeholder satisfaction, innovation and learning, and financial performance) and sixteen items were selected for RC. These items were rated on five point Likert scale. The results in Table 5 indicate mean value of 4.3477 means, $86.954 \%$ of items covered show its applicability to organized NLR. The correlation matrix shown in the Table 6 shows Inter-item Correlations: Mean $=0.214 ;$ Minimum $=-0.0496$; Maximum $=0.971$; Range $=1.0206 ;$ Max $/$ Min $=-19.5699 ;$ Variance $=$ 0.0718 . The proposed confirmatory structural model was tested using AMOS 4.0 version. The results for proposed confirmatory model are shown in Figure 2.

\subsubsection{Confirmatory Model Results}

The confirmatory model loadings are shown in Figure 2. The loadings for the strategic challenge $(\mathrm{RC} 1)$ range from 0.96 to 0.98 . The loading for specialized skills was 
Table 5. Mean and standard deviation for retail challenges and organizational performance.

\begin{tabular}{|c|c|c|c|}
\hline Code & Items & Mean & SD \\
\hline $\mathrm{C} 1$ & Real Estate Cost & 3.3607 & 1.1676 \\
\hline $\mathrm{C} 2$ & Multiple Taxes & 3.4403 & 1.0976 \\
\hline $\mathrm{C} 3$ & Inadequate Infrastructure & 3.3632 & 1.1550 \\
\hline $\mathrm{C} 4$ & Karyana Stores & 3.4502 & 1.0935 \\
\hline $\mathrm{C} 5$ & Specialized Skills & 3.8209 & 0.9876 \\
\hline C6 & Transparency & 3.8209 & 0.9774 \\
\hline $\mathrm{C} 7$ & Manpower Management & 3.8159 & 0.9739 \\
\hline $\mathrm{C} 8$ & Product Sourcing & 3.8383 & 0.9638 \\
\hline $\mathrm{C} 9$ & Customer Loyalty & 4.4254 & 0.6039 \\
\hline $\mathrm{C} 10$ & High Connectivity & 4.4303 & 0.5793 \\
\hline $\mathrm{C} 11$ & Quick Response & 4.4353 & 0.5624 \\
\hline $\mathrm{C} 12$ & Service levels & 4.4403 & 0.5540 \\
\hline $\mathrm{C} 13$ & Operations Management & 4.7289 & 0.8841 \\
\hline $\mathrm{C} 14$ & Operational Cost & 4.8159 & 0.6245 \\
\hline $\mathrm{C} 15$ & Forecasting & 4.8930 & 0.4069 \\
\hline $\mathrm{C} 16$ & SC Performance & 4.8881 & 0.4236 \\
\hline OP1 & Market Performance & 4.9453 & 0.4544 \\
\hline OP2 & SC Competencies & 4.9378 & 0.4775 \\
\hline OP3 & Stakeholder Satisfaction & 4.9428 & 0.4458 \\
\hline OP4 & Innovation \& Learning & 4.9478 & 0.4234 \\
\hline OP5 & Customer Satisfaction & 4.9527 & 0.4121 \\
\hline OP6 & Financial Performance & 4.9552 & 0.4093 \\
\hline
\end{tabular}

Grand Mean $=4.3477, \mathrm{~N}$ of Cases $=402.0, \mathrm{~N}$ of Items $=22$, Alpha $=0.8747$.

Table 6. Correlation for retail challenges and organizational performance.

\begin{tabular}{|c|c|c|c|c|c|c|c|c|c|c|c|c|c|c|c|c|c|c|c|c|c|c|}
\hline & $\mathrm{C} 1$ & $\mathrm{C} 2$ & $\mathrm{C} 3$ & $\mathrm{C} 4$ & $\mathrm{C} 5$ & C6 & $\mathrm{C} 7$ & $\mathrm{C} 8$ & C9 & $\mathrm{C} 10$ & $\mathrm{C} 11$ & $\mathrm{C} 12$ & $\mathrm{C} 13$ & $\mathrm{C} 14$ & $\mathrm{C} 15$ & $\mathrm{C} 16$ & OP1 & OP2 & OP3 & OP4 & OP5 & OP6 \\
\hline $\mathrm{C} 1$ & 1.0 & & & & & & & & & & & & & & & & & & & & & \\
\hline $\mathrm{C} 2$ & 0.956 & 1.0 & & & & & & & & & & & & & & & & & & & & \\
\hline $\mathrm{C} 3$ & 0.970 & 0.942 & 1.0 & & & & & & & & & & & & & & & & & & & \\
\hline $\mathrm{C} 4$ & 0.941 & 0.971 & 0.942 & 1.0 & & & & & & & & & & & & & & & & & & \\
\hline $\mathrm{C} 5$ & 0.203 & 0.082 & 0.180 & 0.038 & 1.0 & & & & & & & & & & & & & & & & & \\
\hline $\mathrm{C} 6$ & 0.205 & 0.088 & 0.190 & 0.052 & 0.964 & 1.0 & & & & & & & & & & & & & & & & \\
\hline $\mathrm{C} 7$ & 0.208 & 0.071 & 0.175 & 0.036 & 0.946 & 0.935 & 1.0 & & & & & & & & & & & & & & & \\
\hline $\mathrm{C} 8$ & 0.183 & 0.082 & 0.185 & 0.050 & 0.960 & 0.959 & 0.941 & 1.0 & & & & & & & & & & & & & & \\
\hline C9 & 0.450 & 0.413 & 0.454 & 0.363 & 0.199 & 0.193 & 0.163 & 0.131 & 1.0 & & & & & & & & & & & & & \\
\hline $\mathrm{C} 10$ & 0.482 & 0.450 & 0.440 & 0.426 & 0.157 & 0.158 & 0.128 & 0.112 & 0.816 & 1.0 & & & & & & & & & & & & \\
\hline $\mathrm{C} 11$ & 0.455 & 0.428 & 0.428 & 0.406 & 0.190 & 0.165 & 0.133 & 0.135 & 0.790 & 0.801 & 1.0 & & & & & & & & & & & \\
\hline $\mathrm{C} 12$ & 0.413 & 0.390 & 0.400 & 0.384 & 0.144 & 0.206 & 0.132 & 0.152 & 0.751 & 0.776 & 0.792 & 1.0 & & & & & & & & & & \\
\hline C13 & 0.356 & 0.134 & 0.314 & 0.096 & 0.533 & 0.515 & 0.562 & 0.490 & 0.310 & 0.287 & 0.258 & 0.224 & - 1.000 & & & & & & & & & \\
\hline C14 & 0.358 & 0.140 & 0.314 & 0.100 & 0.521 & 0.501 & 0.502 & 0.481 & 0.301 & 0.275 & 0.243 & 0.206 & 0.885 & 1.0 & & & & & & & & \\
\hline $\mathrm{C} 15$ & 0.291 & 0.128 & 0.247 & 0.086 & 0.461 & 0.441 & 0.441 & 0.407 & 0.429 & 0.280 & 0.248 & 0.209 & 0.675 & 0.668 & 1.0 & & & & & & & \\
\hline $\mathrm{C} 16$ & 0.253 & 0.085 & 0.211 & 0.044 & 0.417 & 0.397 & 0.397 & 0.365 & 0.226 & 0.359 & 0.163 & 0.126 & 0.684 & 0.676 & 0.523 & 1.0 & & & & & & \\
\hline OP1 & 0.084 & 0.058 & 0.047 & 0.060 & -0.033 & $3-0.033$ & 0.056 & -0.032 & -0.024 & 0.128 & -0.024 & -0.023 & $3-0.037$ & -0.036 & -0.032 & 0.175 & 1.0 & & & & & \\
\hline $\mathrm{OP} 2$ & -0.027 & 0.038 & -0.027 & -0.018 & 0.003 & 0.003 & 0.002 & 0.049 & 0.023 & 0.025 & 0.138 & 0.028 & -0.040 & -0.038 & -0.034 & -0.034 & 0.168 & 1.0 & & & & \\
\hline $\mathrm{OP} 3-$ & -0.037 & -0.030 & 0.040 & -0.029 & -0.023 & $3-0.024$ & -0.024 & -0.022 & 0.100 & -0.049 & -0.050 & 0.112 & -0.039 & -0.038 & -0.034 & -0.034 & 0.1320 & 0.241 & 1.0 & & & \\
\hline $\mathrm{OP} 4$ & 0.114 & 0.109 & 0.115 & 0.132 & -0.028 & $3-0.029$ & -0.029 & -0.027 & 0.029 & 0.153 & 0.033 & 0.035 & 0.149 & 0.039 & 0.025 & 0.023 & 0.0890 & 0.1690 & 0.143 & 1.0 & & \\
\hline OP5 & 0.046 & 0.057 & 0.047 & 0.058 & 0.065 & 0.016 & 0.016 & 0.018 & -0.009 & -0.009 & 0.164 & -0.007 & $7-0.035$ & 0.121 & -0.030 & -0.030 & 0.0390 & 0.0860 & 0.0800 & 0.072 & 1.0 & \\
\hline
\end{tabular}

Inter-item Correlations: Mean = 0.214; Minimum =-0.0496; Maximum =0.971; Range = 1.0206; Max/Min = -19.5699; Variance =0.0718. 
Table 7. Effect estimates for confirmatory factor model.

\begin{tabular}{|c|c|c|c|c|c|}
\hline \multicolumn{6}{|c|}{ Total Effects } \\
\hline & op & $\mathrm{rc} 4$ & $\mathrm{rc} 1$ & $\mathrm{rc} 3$ & $\mathrm{rc} 2$ \\
\hline $\mathrm{rc} 4$ & -0.097 & - & 0.000 & 0.000 & 0.000 \\
\hline $\mathrm{rc} 1$ & -0.111 & 0.653 & 0.000 & 0.000 & 0.000 \\
\hline $\mathrm{rc} 3$ & 0.707 & 0.219 & 0.000 & 0.000 & 0.000 \\
\hline $\mathrm{rc} 2$ & 1.330 & 0.366 & 0.000 & 0.000 & 0.000 \\
\hline \multicolumn{6}{|c|}{ Direct Effects } \\
\hline $\mathrm{rc} 4$ & -0.097 & 0.000 & 0.000 & 0.000 & 0.000 \\
\hline $\mathrm{rcl}$ & -0.048 & 0.653 & 0.000 & 0.000 & 0.000 \\
\hline $\mathrm{rc} 3$ & 0.729 & 0.219 & 0.000 & 0.000 & 0.000 \\
\hline $\mathrm{rc} 2$ & 1.365 & 0.366 & 0.000 & 0.000 & 0.000 \\
\hline \multicolumn{6}{|c|}{ Indirect Effects } \\
\hline $\mathrm{rc} 4$ & 0.000 & 0.000 & 0.000 & 0.000 & 0.000 \\
\hline $\mathrm{rc} 1$ & -0.063 & 0.000 & 0.000 & 0.000 & 0.000 \\
\hline $\mathrm{rc} 3$ & -0.021 & 0.000 & 0.000 & 0.000 & 0.000 \\
\hline $\mathrm{rc} 2$ & -0.035 & 0.000 & 0.000 & 0.000 & 0.000 \\
\hline
\end{tabular}

Remarks: Chi-square $=2476.039$, Degree of freedom $=201$, Level of significance $=0.000$. The values for fit indices have RMR $=0.05, \mathrm{NFI}=0.8, \mathrm{RFI}=0.8$, $\mathrm{IFI}=0.8, \mathrm{TLI}=0.8, \mathrm{CFI}=0.8$. Hypothesis $\mathbf{H 1}$ and $\mathbf{H} 2$ are supported.

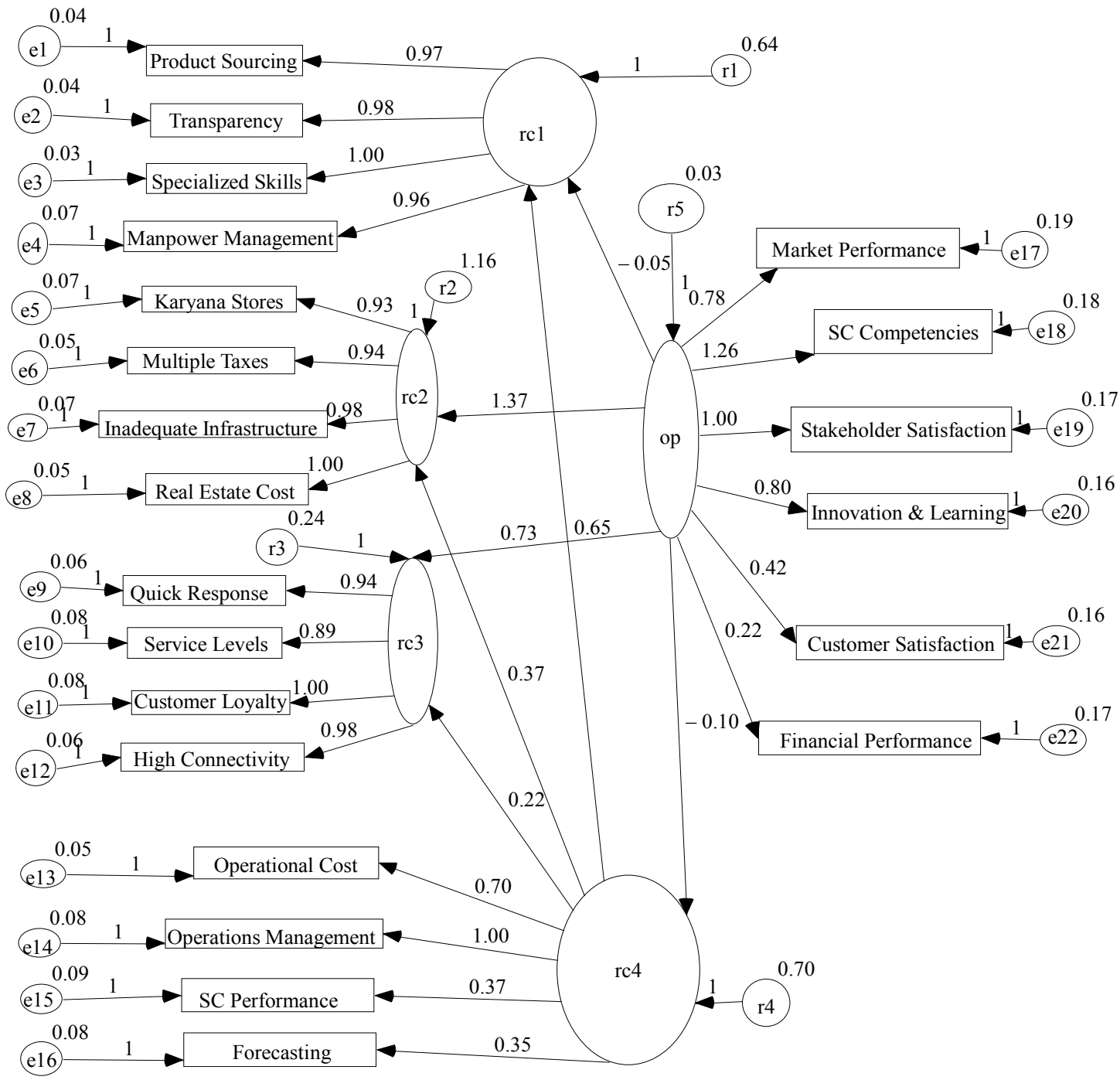

Figure 2. Confirmatory model for retail challenges and organizational performance. 
set at 1.0. The loading for environmental challenges ( $\mathrm{RC} 2$ ) range from 0.93 to 0.98 and loading for real estate cost was set to 1.0. The loadings for customer challenges (RC3) range from 0.89 to 0.98 and loading for customer loyalty was set to 1.0. The loading for SC challenges (RC4) range from 0.35 to 0.70 and operations management was set at 1.0 loading. The loading for organizational performance range from 1.26 to 0.22 and the loading for stakeholder satisfaction was set to 1.0. Also, the loading range for $\mathrm{RC}$ factors and $\mathrm{OP}$ varies from -0.05 to 1.37. The model has Chi-square $=2476.039$, Degree of freedom $=201$, Level of significance $=0.000$. The values for fit indices have $\mathrm{RMR}=0.05, \mathrm{NFI}=0.8, \mathrm{RFI}=$ $0.8, \mathrm{IFI}=0.8, \mathrm{TLI}=0.8, \mathrm{CFI}=0.8$. All these values are acceptable to validate the model. Here, it is pertinent mention that values for fit indices: NFI, RFI, IFI, TLI, and $\mathrm{CFI} \geq 0.8 \mathrm{RMR}$ value $\leq 0.05$ and chi-square level of significance $\geq 0.05$ is good enough for structural validity of the model $[21,18]$. The effect estimates are shown in Table 6. The results indicate that the total effects of retail challenges on organizational performance are significant. Also, SC challenges are significantly influenced by strategic challenges, environmental challenges, and customer challenges.

\section{Discussion, Limitations and Future Research}

The results in the Figure 2 indicate that all the items load significantly on their respective factors indicating the applicability and contribution. The total effect estimates (Table 7) show that the total effect was highest for environmental challenges on OP followed by customer challenges. The discussion with organized NLR practitioners revealed that these two challenges are most difficult to control hence maximum attention need to be focused on them. Also the discussion on total effect for strategic challenge $(-0.111)$ and SC challenge $(-0.097)$ revealed that these challenges are internal to the organizations and shall be solved by inputs from R\&D or consultants. Here, it was also interesting to point out that the organized NLR practitioners understand the importance of SC challenges. The total effect estimate for strategic challenges (0.653), environmental challenges (0.366), and customer challenge (0.219) on SC challenges. It clearly indicates that understanding of organized NLR practitioners for the same. Hence the hypothesis $\mathrm{H} 1$ and $\mathrm{H} 2$ are proved.

However, despite the statistical sophistication of confirmatory technique more was needed to understand the retail challenges and the organizational performance. Here, it is pertinent to mention that in different stages of organizational life cycle the RC and OP items and factors are also different. It was also interesting to note that along with organized retailers traditional retailers are also improving. Hence, to understand the dynamics, it is needed to study customers, organized retailers, and traditional retailers together for identification of better gaps between organized and traditional retailers.

\section{REFERENCES}

[1] A. Neely, C. Adams and M. Kennerley, "The Performance Prism-The Scorecard for Measuring and Managing Success," Pearson Education Limited, London, 2002.

[2] R. Rajmohan, "India Retail Report 2007," IMAGES, F \& R Research, India, 2007.

[3] R. Rajmohan, "India Retail Report 2009," IMAGES, F \& R Research, India, 2009.

[4] P. Neetu, "Retailing Revolution in India: An Overview," The Management Accountant, Accountant, Vol. 42, No. 10, 2007, pp. 764-66.

[5] S. Pradhan, "Retailing Management Text and Cases," Tata McGraw-Hill, Publishing Company Limited, New Delhi, 2007.

[6] A. J. Newman and P. Cullen, "Retailing Environment and Operations," Cengage Learning India Private Limited, New Delhi, 2002.

[7] P. K. Sinha and D. P. Uniyal, "Managing Retailing," Oxford University Press, New Delhi, 2007.

[8] S. Jack, "Challenges of the Future: The Rebirth of Small Independent Retail in America," IRMA, 2004, pp.10-22. http://www.retail-revival.com

[9] G. Kapoor, "Revolutionizing the Retail Industry in India," Proceedings of the 51th World Business Summit, CIES, The Food Business Forum, 20-22 June 2007, pp. 211-35.

[10] P. Bhatia and A. Sharma, "India's Organised Retail Players Rethinking Strategy," The Economic Times, India, 27 September 2008. http://www.theeconomics times.com

[11] S. Yamin, A. Gunasekruan and F. T. Mavondo, "Relationship Between Generic Strategy, Competitive Advantage and Firm Performance: An Empirical Analysis," Technovation, Vol. 19, No. 8, 1999, pp. 507-518. doi:10.1016/S0166-4972(99)00024-3

[12] E. W. Anderson, C. Fornell and D. R. Lehmann, "Customer Satisfaction, Market Share, and Profitability: Findings from Sweden," Journal of Marketing, Vol. 58, No. 3, 1994, pp. 53-66. doi:10.2307/1252310

[13] S. Chopra and P. Meindle, "Supply Chain Management: Strategy, Planning, and Operations," Pearson PrenticeHall, Upper Saddle River, 2004.

[14] A. A. Katou and P. S. Budhwar, "Casual Relationship Between HRM Policies and Organizational Performance: Evidence from Greek Manufacturing Sector," European Management Journal, Vol. 28, No. 2, 2010, pp. 25-39. doi:10.1016/j.emj.2009.06.001

[15] W. G. Kenneth, D. Whitten and R. A. Inman, "The Impact of Logistics Performance on Organizational Performance in the Supply Chain Context," Supply Chain 
Management: An International Journal, Vol. 13, No. 4, 2008, pp. 317-327.

[16] K. W. Green, and R. A. Inman, "Using a Just-in-Time Selling Strategy to Strengthen Supply Chain Linkages," International Journal of Production Research, Vol. 43, No. 16, 2005, pp. 3437-3453.

[17] N. Vivek, and S. Ravindran, "An Empirical Study on the Impact of Supplier Performance on Organizational Performance: A Supply Chain Perspective," South Asian Journal of Management, Vol. 61, No. 3, 2009, pp. 61-70.

[18] J. F. Hair, R. E. Anderson, R. L. Tatham and W. C.
Black, "Multivariate Data Analysis," Prentice Hall, Englewood Cliffs, 2009.

[19] M. S. Bartlett, "Tests of Significance in Factor Analysis," British Journal of Statistical Psychology, Vol. 3, No. 2, 1950, pp. 77-85.

[20] L. J. Cronbach, "Coefficient Alpha and the Internal Structure of Tests," Psychometrika, Vol. 16, No. 3, 1951, pp. 297-507. doi:10.1007/BF02310555

[21] M. W. Browne and R. Cudeck, "Alternative Ways of Assessing Model Fit, in Testing Structural Equation Models," Sage Publication, 1993. 